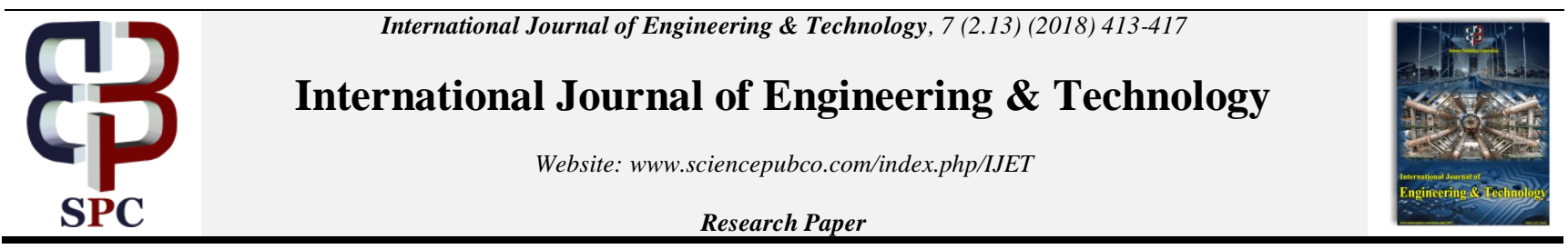

\title{
Collaborative Assessment Using QR-Code on Ethno- mathematics Learning for Pre-Service Teacher
}

\author{
Ratri Rahayu ${ }^{1^{*}}$, Himmatul Ulya ${ }^{2}$, Kartono $^{3}$, Isnarto $^{4}$, Nuning Kurniasih $^{5}$ \\ ${ }^{1 *}$ Mathematics Education Department, Universitas Muria Kudus, Indonesia \\ ${ }^{2}$ Mathematics Education Department, Universitas Muria Kudus, Indonesia \\ ${ }^{3}$ Mathematics Education Department, Universitas Negeri Semarang, Indonesia \\ ${ }^{4}$ Mathematics Education Department, Universitas Negeri Semarang, Indonesia \\ ${ }^{5}$ Faculty of Communication Sciences, Library and Information Science Program, Universitas Padjadjaran, Bandung, Indonesia \\ *Corresponding authorE-mail: ratri.rahayu@umk.ac.id
}

\begin{abstract}
This research is aimed to analyze the needs of collaborative assessment tools on ethno-mathematics learning. The subjects of this research are four lecturers of ethno-mathematics course, 87 college students in their $6^{\text {th }}$ semester, and the head of Elementary Teacher Education study program of Faculty of Teacher Training and Education of Universitas Muria Kudus, Indonesia. The data is obtained from literary study and field surveys which includes documentation, questionnaire and interview. The technique used to analyze the data is data triangulation which consists of several steps, those are: reduction, data presentation, and conclusion based on the data description. The result of this research showed that (1) the students were not involved in making of ethno-mathematics learning assessment tools; (2) generally, the lecturers were lack in understanding that they did not applied the collaborative assessment on the ethno-mathematics learning; (3) assessment tools were needed to measure mathematical ability using QR-Code and students' disposition; (4) the lecturers expect that the guide book will provide the concept of collaborative assessment by using communicative language that detailed and practical so that it could be applied easily; (5) the guidebooks can accommodate lecturers' expectations.
\end{abstract}

Keywords: collaborative assessment, ethno-mathematics, mathematical ability, QR-Code, information technology

\section{Introduction}

Mathematic has a very important role in supporting one's activity in life. A person who has a good mathematical ability will be able to think creatively, analytically, critically, systematically, and logically [1]-[7]. A mathematical ability is needed to help people solve problems of live. The effort made to achieve good mathematical ability is through learning mathematics in school.

The Indonesia's government established the 2013 curriculum that not only prioritizes knowledge skills, but also attitudes and skills for some reasons. In this curriculum, mathematics teachers are required to be able to approach mathematical concepts with students' daily activity so that they can learn contextually. The purpose is for students to know directly the role of mathematics in real life and recognize the culture that exist in their environment. This approach of learning is aimed to avoid mechanical learning of mathematics that does not relate mathematics to real life which leads to low students' result [8]. The application of 2013 curriculum in Indonesia is in accordance with mathematics learning based on culture or so called ethno-mathematics.

Ethno-mathematics learning facilitates student to learn by observing and analyzing social activities, local excellence, and historical sites related to mathematical concepts. It will involves students directly and make the learning becomes meaningful. In addition, ethno-mathematics learning is more effective in improving mathematics study result[9]. The learning of ethno-mathematics makes students interested and eager in learning mathematics[10].
Based on the advantages of ethno-mathematics, Elementary Teacher Education Study Program (PGSD) of Universitas Muria Kudus (UMK) establishes ethno-mathematics as one course in the study. This course aims to help the pre-service teacher in the program study has good mathematical ability as well as able to relate the culture to the concept of math. Many teachers find it difficult connecting the local culture with the learning material[11]. The teacher must empower all of her potential in order to integrate the work and local cultural values in the mathematics subject matter [12][13]. The mathematical disposition of pre-service teachers will emerge as they analyze the various roles of mathematics in around culture. By possessing a good level of mathematical ability and disposition it will create a good impact on effective learning to improve student study result.

However, the pre-service teachers are knowing their around culture, but fails to apply it in math context. The ability of communication, connection, problem solving, and creativity of the preservice teachers need to be measured precisely as this mathematical ability is needed to teach the students. Teacher makes the important role in learning[14]. Therefore, a teacher should have a well-built mathematical ability and disposition so that they will be confident, curious and undespair in solving problem. Disposition is a faith of a person who believe that mathematics plays an important role in life. Mathematical disposition is the affective domain which has important role in the mathematics learning[15].

An assessment is important[16] to know the success of learning. Likewise, ethno-mathematics learning has an evaluation tool that 
is needed to find out the profile of the pre-service teacher in terms of mathematical ability and disposition on ethno-mathematics learning. If an assessment tools is not compiled properly as the guidelines without pay attention to its validity and reliability, then the quality of ethno-mathematics learning will be unknown. Furthermore teachers' assessment literacy is the key link to connect the quality of the assessment and student achievement[17]. Therefore, a study is needed to analyze the needs of assessment tools in ethno-mathematics learning at Muria Kudus University.

Collaborative assessment can support ethno-mathematics learning by involving students in building the instruments. All this time, evaluation conducted by lecturers does not involve students. As the result of the unilateral assessment, the students' thoughts and aspirations are being ignored. In collaborative assessment, students are not only an assessment object but also the subject of the assessment. Assessment of study result is not only decided absolutely by the lecturers but also the self-assessment of students and colleagues need to be included. Collaborative assessment helps students to know the topic and criteria of the assessment as well as to be directly involved in the process.

Since collaborative assessment is not used by many ethnomathematics lecturers to measure the students' ability, so it is the time to introduce it. The purpose is to support the lecturer in performing the collaborative assessment properly as one of result assessment of ethno-mathematics course. Therefore, the development of a collaborative assessment model is an urgent need to improve student learning outcomes. One of the media can used is QR-code. The purpose of using QR-Code in addition to technology utilization efforts can also be a media that can make students become enthusiastic in working on the problem of mathematical thinking ability.

Before developing the collaborative assessment model products, factual and depth study need to be done in the implementation of assessment conducted by the lecturer. The purpose is to maximize the study result and benefits of developing a collaborative assessment model. The preliminary study aims to reveal lecturers knowledge of collaborative assessment, lecturer and student expectations of collaborative assessment manuals, and the development of a collaborative assessment model draft. Then, the draft of collaborative assessment model will be developed into a collaborative assessment guide.

\section{Method}

This research used qualitative approach. The main activities undertaken in this research were field survey and literary review. The field survey used techniques of collecting questionnaires, interviews, and study documentation and in order to obtain information about learning conditions and the implementation of collaborative assessments, it required lecturers, students, and heads of elementary education teacher study programs. Semi-structured interviews were conducted for 4 lecturers of ethno-mathematics courses and head of elementary education teacher education program. Questionnaires were given to 87 PGSD students. Questionnaire was related to the perception, feelings, and desires on learning and assessment in ethno-mathematics course. Documents used in this study were curriculum documents, instructional tool documents and lecturer appraisals, personal documents, as well as journals relevant to this research.

The second activity was literary review and recording. Both of the data were used as reference and the basis of product development in the form of guidebook of collaborative assessment. The literary review of collaborative assessment was discussed in a focus group discussion (FGD) forum by involving the expert of learning assessment, mathematics learning, and ethno-mathematics to get some inputs as the material for developing the guidebook collaborative assessment.
The technique of data analysis used in this research was data triangulation which consisted of three stages: reduction, data presentation, and conclusion based on data description. The result of questionnaire data given to the students was presented as a percentage. Meanwhile, the analysis of qualitative descriptive data was used for the interview result, document study of learning instrument, and assessment by lecturer. The literary review data and FGD results as the inputs from the experts on the model of collaborative assessment were analyzed using qualitative descriptive techniques.

\section{Findings}

\subsection{The Lecturers' Knowledge Condition on Collabora- tive Assessment}

The researcher conducted interviews and documentation studies to find out the state of collaborative assessment knowledge of the lecturers. Interviews were conducted to four lecturers of ethnomathematics courses. From the interview result, the researcher could obtain some information about their opinion, attitude, and experience in doing the assessment on the students. By interviewing the lecturer, it was found that lecturers did not read the standard of learning appraisal in national standard of college (SNPT). During this time they only conducted an evaluation based on experience that had been done without looking at the assessment standards. They had attended a college curriculum review workshop, but they admitted to being overworked so they did not have time to follow the assessment procedure in accordance with the curriculum. This certainly affected the quality assurance of the results of the evaluation that had been done.

Ethno-mathematics lecturers evaluated students' learning achievements in the realm of knowledge and skills. The lecturer had never evaluated the attainment of attitude competency. Some lecturers had conducted disposition assessments for elementary school students, but they had never done a mathematical disposition assessment to pre-service elementary school teachers. Thus, they had not known about students' mathematical disposition even though it was very useful for teacher. However, a guidebook which contains the development of mathematical disposition rubric was required for the teachers.

In regard with the lecturers' understanding of collaborative assessment, it was revealed that they still lack in it. During this time, the lecturer assumed that students were not supposed to be involved in carrying the assessment. They felt entitled to decide the instruments, criterion, indicators, and assessment value without making any agreement with the students. Whereas the SNPT assessment standards said that the assessment process and study result should be based on standards agreed by both of the lecturers and students. Lecturers expressed their desire to increase their knowledge on collaborative assessment as they recognized that the assessment was an important part of learning even though they had not done it according to the mechanism set by the curriculum.

Based on documentary studies by looking at the evaluation documents made by lecturers, it was known that mathematical capability and disposition assessments had not been implemented. Lecturers had made math problems related to culture, but without paid attention to the mathematical ability to be achieved by students. Mathematical ability made by lecturers had not refers to a problem that will measure students' high-level thinking skills. Problems were made only for measuring mathematical understanding that prioritized mechanical work, and they also made a problem without providing the outline and assessment guides. "Too busy" became the lecturers' reason why they did not make an intact learning instrument.

After looking at the assessment documents made by lecturers, it revealed that the discussion depth of ethno-mathematical studies simply around Kudus District. This was because three of the four 
lecturers of ethno-mathematics courses were originally from $\mathrm{Ku}$ dus District. They had not recapped the origin of the students. The lecturer assumed ethno-mathematics as merely a local advantage, and less deeply learned that cultural-based learning included local wisdom, tradition, and social life.

Based on the interviews with the head of the PGSD study program, the researcher noted that the lecturers were very busy with researches and dedications activities. As the result, learning evaluation activities were being ignored. It was very rare to find lecturers who were able to involve the students on the assessment. The lecturers just concerned to assess on aspects of knowledge, while the aspects of skills and attitudes had not been maximally implemented. This far, the profile of mathematical ability and disposition of the pre-service teacher from PGSD study program was not identified. The interviews with lecturers and head of PGSD study program concluded that the lecturer of ethno-math course had not conducted a collaborative assessment, so there was a need for practical guidance which included mechanisms and the examples of evaluation instruments of students' mathematical ability and disposition.

\subsection{The Results of Students' Questionnaires}

The researchers spread questionnaires to 87 students of PGSD UMK. From the questionnaires, it could be seen the students' perceptions and feelings in following the learning of ethnomathematics, experiencing the assessment process, and their desire to be involved in the assessment. Table 1 showed the results of the questionnaire.

Table 1: Students' Needs Analysis

\begin{tabular}{|c|c|c|}
\hline No & Indicator & Result \\
\hline 1 & $\begin{array}{c}\text { Students' perceptions towards Ethno-Mathematics learn- } \\
\text { ing }\end{array}$ & $85,5 \%$ \\
\hline 2 & Students' feeling when learning the Ethno- Mathematics & $82 \%$ \\
\hline 3 & Students' experience in assessment process & $42,2 \%$ \\
\hline 4 & Students' desire to be involved in the assessment process & $87,80 \%$ \\
\hline
\end{tabular}

Based on the data analysis in table 1 , it can be concluded that the students' perception in the learning of ethno-mathematics is good The pre-service teachers argue that math is beneficial to life. They have a positive thinking for ethno-mathematics learning which means they loved ethno-mathematics learning. However, students still have a poor experience in the assessment process. This is proven by their study result which is less satisfactory. They have a high desire to be involved in the assessment process.

\subsection{Lecturers' Expectation on the Guidebook of Col- laborative Assessment}

After the interview, it was possible to know the lecturers' expectation of the collaborative assessment manual. They hoped the guidebook should use communicative, clear, and understandable language. The book should contained theories and concepts concerning ethno-mathematical learning, mathematical thinking skills, mathematical dispositions, and collaborative assessment as well as strategy for the application of such concepts. The guidebook should refer to the current curriculum (the DTL). Besides, lecturers want many examples of mathematical abilities and disposition scales and the book to be arranged in a practical and detailed so it could be applied easily.

\subsection{Suggestions from Focus Group Discussion (FGD)}

In order to develop guidelines for collaborative assessment that met the field needs, a Focus Group Discussion (FGD) was conducted by the experts of assessment, mathematics learning and ethno-mathematics. Through the discussions, inputs were used as a provision of guidelines for collaborative assessment. Summaries of the experts' input as follows.
1. The conceptual definition of collaborative assessment, mathematical ability, and disposition should be discussed thoroughly.

2. Collaborative assessment manuals should really measure students' high-level mathematical skills and dispositions and not only measuring the mastery of mathematical concepts.

3. Arrangement of the rubric assessments should be provided for all mathematical thinking skills including conceptual understanding, communication, connection, reasoning, problem solving, creative thinking, and critical thinking followed by sample questions in each indicator.

4. Method of writing about mathematical ability had to be operational and able to fulfil the element of readability.

5. Cultures in East-side of Java North Coast Road include Semarang, Demak, Jepara, Kudus, Pati, and Rembang that would be linked to problems of solving abilities.

6. The disposition scale was explained based on the ability of mathematical thinking.

\subsection{The Outline of Collaborative Assessment Guide- book}

After the needs analysis, a collaborative assessment model of the learning of ethno mathematics would be developed. This development product was a guidebook that was expected to be guidance for the lecturers in conducting the assessment of students' mathematical and disposition ability in ethno-mathematics course. Therefore, a literary review was performed regarding collaborative assessment, ethno-mathematics learning, mathematical ability, disposition and related matters to obtain a clear picture. In addition, input from experts in FGD was being created as an outline draft of the collaborative assessment guidebook on ethnomathematics learning to measure students' mathematical and disposition ability. Here is the outline of the draft.

\section{Chapter 1}

\section{Collaborative Assessment on Ethno-mathematics}

Learning

1.1. Collaborative assessment

1.2. Ethno-mathematics learning

1.3. The needs of collaborative assessment on ethnomathematics learning

1.4. The purpose

\section{Chapter 2}

\section{Assessment of Mathematical Thinking Ability on Ethno-} mathematics Learning

2.1. The definition of mathematical thinking ability

2.2. The types and level of mathematical thinking

2.3. Assessment of mathematical ability on ethnomathematics learning.

\section{Chapter 3}

Mathematical Dispositions on Ethno-mathematics

Learning

3.1. The definitions of mathematical dispositions

3.2. Indicators

3.3. How to arrange the dispositions scale on ethnomathematics learning

3.4. Instruments of mathematical dispositions scale.

\section{Chapter 4}

Collaborative Assessment Guidebook

4.1. The periods of conducting the collaborative assessment

4.2. The methods of collaborative assessment

\section{Discussion}

The highest productivity of lecturers in doing Tri Dharma (three main tasks) was in the field of education and teaching. However, the focus of lecturers in teaching was to arrange the preparation of teaching and to implement the learning while the aspects of as- 
sessment were not considered by lecturers. The same thing happened in PGSD UMK. Lecturers did not have sufficient experience in developing assessment instruments, whereas they were competently able to do so. Means and opportunities for the assessments development of students had been obtained enough. All lecturers had attended workshops of Basic Instructional Skills Improvement and applied approach, one of the training program. In the workshop lecturers were given experience how to conduct an assessment of the students. Although they had already understood, but they had not done it in class.

Based on the interview result, it was known that lecturers had not conducted collaborative assessment in learning. The lecturers had not invited students directly in the assessment activities. Though, SNPT had recommended that lecturers and students had to make an agreement on standard assessment of students' study result. In addition, lecturers also do not update the assessment trends based on reputable journals. Even the lecturer's knowledge of journal indexing in SINTA, DOAJ, Google Scholar, SCOPUS, and Web of Science databases only reached $66.5 \%$ [18].

The low involvement of students in the assessment process could be seen in student questionnaires although they had a great desire to be involved in the assessment. Although their perceptions and feelings when they follow the course of ethno-mathematics had been good already, they still had a poor experience in the assessment process. If unilateral assessment was conducted continuously, there were a worrisome that PGSD graduate students as preservice teachers were not aware of the assessment techniques.

One of the objectives of student involvement in the assessment was to have them know the standard of assessment and practice directly in the discussion of the criteria of assessment conducted. Students as the pre-service teachers had to know and understand the standards of educational assessment, because according to the Regulation of the Minister of National Education No. 23 of 2016 teachers had an important role in assessing students. It was expected that the pre-service teachers could adjust to the current curriculum assessment standards [19].

One of the pedagogic competencies of teachers as stipulated in the Regulation of the Minister of National Education No. 16 of 2007 on Academic Qualification Standards and Teacher Competencies was to conduct assessment and evaluation of learning process and outcomes. It was clear that in the law, teachers had to have the competence to administer process assessments and learning outcomes on an ongoing basis by using various instruments.

Referring to the SNPT, student learning achievement included aspects of knowledge, attitude, and skills. Assessment on aspects of attitude, especially mathematical dispositions, had not been implemented in ethno-mathematics learning though the disposition of ownership was very important. If students had high mathematical dispositions, their desire and interest towards mathematics would be high[20]. A strong and good mathematical disposition would play a role in fostering the urge to continue trying to produce a resilient personality. In addition, students would be confident and enthusiastic in achieving the best outcomes of mathematics learning.

Mathematics assessments had been done only on assessments that tested mechanical ability. The assessment had not been directed to high-level math skills. Whereas if the pre-service teacher had good math skills, it would certainly have an impact on his ability in delivering material to students. The same thing conveyed by Marbun who stated that the competence of teachers could contribute to the improvement of learning achievement that it could give an active role-model, creative, innovative, and high integrity in school[21].

High level math capability of each person could be developed i.e. the ability to think critically. Critical thinking was the natural potential of a person; it could be measured, trained, and developed. If critical thinking was sharpened continuously, it could become a habit. This habit would be the basic attitude, which ultimately forms the disposition of critical thinking.

Assessment of high-level mathematical ability could be facilitated by associating mathematics with culture (ethno-mathematics). The reason was that through ethno mathematics students could easily understand math problems because it was suitable with the environment and daily life. The results of Demitra \& Sarjoko's research found that local culture was suitable for improving students' math skills[22].

In the collaborative assessment there were activities between educators and learners where they were sharing about the criteria selection used in assessment activities [23]. Thus, in the collaborative assessment, students were involved in assessment activities as they discussed and negotiated with the lecturers in relation to the assessment activities that would be undertaken. Collaborative lecturers and students in collaborative assessment is an effort to increase openness and access to scientific work [24].

Lecturers and students needed knowledge of collaborative assessment that could be applied to ethno-mathematics learning. Therefore it was necessary to empower lecturers and students in order to understand and implement it in each class. In this research, form of collaboration procedure which was done was collaboration between lecturers of ethno-mathematics and collaboration between lecturers and students. The strategy used was preparing and training for students.

The stage of preparation was the initial activity of conducting a collaborative assessment. The ethno-mathematics lecturer and students prepared the discussion material including covering the scope or boundaries of the material, the type of assessment that will be used for both mathematical and disposition abilities, ethnomathematics studies, and the design of assessment criteria. The purpose of the training activities was to provide students with initial knowledge that they would be involved in discussions and negotiations on assessment criteria. The agreement was decided based on the results of student discussions with the lecturers that would later become a reference assessment of students' mathematical ability and disposition.

Collaborative assessment on ethno-mathematics learning aimed to determine the profile of students' mathematical ability and disposition. The search for students' mathematical proficiency profile was one of the efforts that could be done by teachers/ lecturers to overcome students' learning difficulties and as an effort to improve students' mathematical ability[10], [25]. In addition, the profile of mathematical ability needed to be known by the teacher in order to know the characteristics of students in solving mathematical problems, so that teachers could plan the learning and evaluation in accordance with the characteristics of these students.

According to Trisnowali, by the knowing the profile of students' mathematical disposition it could be used as a recommendation for teachers to facilitate activities that could lead to students' mathematical disposition, for example, activities in the field of science and technology through various competitions, both national and international scale[26]. It is in line with Sugiyanti \& Prasetyowati who argued that by knowing the profile of mathematical disposition, lecturers could follow up the student constraints with proper handling. Lecturers could cultivate mathematical dispositions through their involvement in collaborative group assessment[27].

During this time, the ethno-mathematical learning that was done refers to the existing culture in the Kudus area while students of PGSD UMK came from many areas such as Jepara, Demak, Semarang, Blora, Pati and Rembang. However, students could tell about the perspective, local excellence, social activities, and local wisdom in each region. Lecturers could explore the cultural diversity of students to be used as an ethno study material that was integrated into learning. 
Understanding of lecturers and students on collaborative assessment was still not maximized. Therefore, the collaborative assessment manuals that will be compiled would not only contain the concept of assessment but also complemented by implementation guidelines and examples of assessment instruments that could be used. Implementation guidelines were given clearly for easy application by both lecturers and pre-service teachers.

Lecturers' expectations of the collaborative assessment mechanism guidebook were generally related to language and content. In terms of language, lecturers wanted that the guidebooks made in a communicative and understandable language, while the content of the book should be in accordance with the DTL and it contains concepts and examples of high-level mathematical and disposition ability. This expectation was still quite reasonable considering they are the users of the guidebook that is expected to contain an easy-to-understand mechanism for collaborative assessment that could be practiced directly in the classroom.

\section{Conclusion}

The results of this study are very important for improving the implementation of the assessment of ethno-mathematics learning. During this time lecturers conducted assessment of knowledge and skills, without considering students' disposition assessment. Mathematical ability made by lecturers had not measured the ability of high-level thinking. Students were not involved in the preparation of the ethno-mathematics learning assessment instruments. Lecturers were lack in understanding and had never applied collaborative assessment on ethno-math learning. Development of assessment tools was needed to measure students' mathematical and disposition abilities. Implications of collaborative assessment included the involvement of students in discussions and agreement on the criteria used in the assessment. The lecturer expected the guidebooks to contain the concept of collaborative assessment and to use communicative, detailed, and practical language so that it could be applied easily; The guidebook draft made was cultivated to be able accommodate the expectations of lecturers.

\section{Acknowledgement}

We would like to extend our gratitude to the various parties who have assisted in the implementation of this research. First, we would like to thank DRPM of the Ministry of Research Technology and Higher Education of Indonesia which has provided grants for research cooperation between universities. Secondly, our thanks go to the Rector of Universitas Muria Kudus University and the Rector of Universitas who have facilitated this research so that it could be able to run well as the provisions. Further thanks to colleagues in FGD and all of the respondents including lecturers, students and various parties that unable to be mentioned one by one. We hope that this research can be useful for various parties and the improvement of ethno-mathematics learning in Indonesia.

\section{References}

[1] A. Rahman and A. S. Ahmar, "Relationship between learning styles and learning achievement in mathematics based on genders," World Trans. Eng. Technol. Educ., vol. 15, no. 1, pp. 74-77, 2017.

[2] N. Arsyad, A. Rahman, and A. S. Ahmar, "Developing a self-learning model based on open-ended questions to increase the students' creativity in calculus," Glob. J. Eng. Educ., vol. 19, no. 2, pp. 143-147, 2017.

[3] A. Rahman et al., "The Implementation of APIQ Creative Mathematics Game Method in the Subject Matter of Greatest Common Factor and Least Common Multiple in Elementary School,” J. Phys. Conf. Ser., vol. 954, no. 1,2018

[4] A. Rahman, A. S. Ahmar, and Rusli, "The influence of cooperative learning models on learning outcomes based on students' learning styles," World Trans. Eng. Technol. Educ., vol. 14, no. 3, 2016.

[5] A. S. Ahmar, A. Rahman, I. Minggi, U. Mulbar, H. Upu, and M. A. Tiro, "The Profile of Creativity and Proposing Statistical Problem Quality
Level Reviewed From Cognitive Style,” J. Phys. Conf. Ser., vol. 954, 2018

[6] A. S. Ahmar and A. Rahman, "Development of teaching material using an Android," Glob. J. Eng. Educ., vol. 19, no. 1, pp. 72-76, 2017.

[7] U. Mulbar, A. Rahman, and A. S. Ahmar, "Analysis of the ability in mathematical problem-solving based on SOLO taxonomy and cognitive style," World Trans. Eng. Technol. Educ., vol. 15, no. 1, pp. 68-73, 2017

[8] T. Laurens, “Analisis Etnomatematika dan Penerapannya dalam Meningkatkan Kualitas Pembelajaran," J. Prodi Pendidik. Mat. STKIP PGRI Sumbar, vol. 3, no. 1, 2016.

[9] S. S. Unodiaku, "Effect of ethno-mathematics teaching materials on students' achievement in mathematics in Enugu State," J. Educ. Pract., vol. 4, no. 23 , pp. $70-77,2013$

[10] H. Ulya and R. Rahayu, "Pembelajaran etnomatematika untuk menurunkan kecemasan matematika," J. Mercumatika J. Penelit. Mat. dan Pendidik. Mat., vol. 2, no. 1, pp. 16-23, 2017.

[11] I. N. Suardana, I. W. Redhana, A. A. Sudiatmika, and I. N. Selamat, "Students' Critical Thinking Skills in Chemistry Learning Using Local Culture-Based 7E Learning Cycle Model.,” Int. J. Instr., vol. 11, no. 2, pp. 399-412, 2018.

[12] R. Rahayu, "Permainan edukasi berbasis keunggulan lokal Dalam pembelajaran matematika," in " Prosiding Seminar nasional: Menumbuhkan kembali Pesona Budaya Bangsa dalam perspektif psikologi,” 2016.

[13] S. Rahayu, N. Ulfatin, and B. B. Wiyono, "The Effect Of Teacher's Concern To Innovation And Emotional Intelligence On The School Effectiveness Mediated By The Professional Competency Of Teachers And School Culture,” Int. J. Educ. Res., vol. 5, no. 12, pp. 1-12, 2017.

[14] Y. Wulandari, E. D. Sartika, and P. Perawati, "Strategi Kepala Sekolah Perempuan dalam Meningkatkan Mutu Pendidikan,” JMKSP (Jurnal Manajemen, Kepemimpinan, dan Supervisi Pendidikan), vol. 3, no. 1, 2018.

[15] R. Rahayu, "Kartono. 2014. The Effect Of Mathemathical Disposition toward Problem Solving Ability Based On IDEAL Problem Solver," Int. J. Sci. Res., vol. 3, no. 10, pp. 1315-1318.

[16] H. Khodabakhshzadeh, Z. Kafi, and M. Hosseinnia, "Investigating EFL Teachers' Conceptions and Literacy of Formative Assessment: Constructing and Validating an Inventory.," Int. J. Instr., vol. 11, no. 1, 2018 H. Ashraf and S. Zolfaghari, "EFL Teachers' Assessment Literacy and Their Reflective Teaching,” Int. J. Instr., vol. 11, no. 1, pp. 425-436, 2018 .

[18] A. S. Ahmar et al., "Lecturers' Understanding on Indexing Databases of SINTA, DOAJ, Google Scholar, SCOPUS, and Web of Science: A Study of Indonesians,” J. Phys. Conf. Ser., vol. 954, 2018.

[19] E. Eliawati, B. Pitoewas, and H. Yanzi, "Sikap Guru Terhadap Standar Penilaian Kurikulum 2013 Berdasarkan Permendikbud Nomor 23," J. Kult. Demokr., vol. 5, no. 4, 2017.

[20] N. Widyasari, J. A. Dahlan, and S. Dewanto, "MENINGKATKAN KEMAMPUAN DISPOSISI MATEMATIS SISWA SMP MELALUI PENDEKATAN METAPHORICAL THINKING," FIBONACCI J. Pendidik. Mat. dan Mat., vol. 2, no. 2, pp. 28-39, 2016.

[21] P. Marbun, "HUBUNGAN IMPLEMENTASI KURIKULUM 2013 TERHADAP HASIL BELAJAR KIMIA SISWA KELAS X SMA N 1 TANJUNG MORAWA TA 2013/2014.” UNIMED, 2015.

[22] S. Sarjoko and D. Demitra, "Pengembangan Model Pembelajaran Kooperatif Handep Berpasangan Berdasarkan Kaidah Quantum Teaching," Indones. J. Curric. Educ. Technol. Stud., vol. 6, no. 1, pp. 6-14, 2018.

[23] N. Falchikov, Improving assessment through student involvement: Practical solutions for aiding learning in higher and further education. Routledge, 2013.

[24] N. Kurniasih, C. Hasyim, A. Wulandari, M. I. Setiawan, and A. S. Ahmar, "Comparative Case Studies on Indonesian Higher Education Rankings," J. Phys. Conf. Ser., vol. 954, 2018.

[25] I. Suharta and I. Suarjana, "A Case Study on Mathematical Literacy of Prospective Elementary School Teachers.," Int. J. Instr., vol. 11, no. 2, pp. 413-424, 2018.

[26] T. Martono, "Kepemimpinan Kepala Sekolah, Kinerja Guru, Budaya Organisasi Sekolah, Pengaruhnya terhadap Produktivitas Sekolah," Surakarta UNS, 2007.

S. Sugiyanti and D. Prasetyowati, "PROFIL DISPOSISI MAtematis Mahasiswa Program Studi Pendidikan Matematika Universitas Pgri Semarang Pada MATA KULIAH KALKULUS INTEGRAL,' Jipmat, Vol. 2, No. 2, 2018. 